\title{
Development Coaching Model of Through School Improve Professionals Teacher In Vocational High School
}

\author{
Rivolan Priyanti Pujihandayani \\ Departement of Education Management \\ State University of Medan \\ Medan, Indonesia \\ Corresponding email: bundarivolan@gmail.com
}

\begin{abstract}
Teacher development is one of the main tasks of school supervisors. In practice, teacher training has not been implemented optimally. One of the causes is the untapped use of media in supporting the implementation of teacher development. The purpose of research and development is to develop teacher development model. The method used is research and development. Implementation of teacher coaching model begins with programming. Furthermore, the supervisor gives a schedule whenever he will carry out teacher training. School supervisors in carrying out guidance of teachers performed consistently, especially in providing guidance through programmed coaching. Data obtained through observation, interviews, and tests. Data were analyzed descriptively qualitative and quantitative. The results showed that: (1) the model of teacher development by the school supervisors developed was tested feasible and effective; (2) the model has also been tested to have a high degree of stability; (3) the model of teacher training by school supervisors has an impact on improving the professional ability of teachers; (4) teacher development model can support the implementation of task of school supervisor especially in conducting programmed teacher development; (5) the developed model can support the implementation of school supervisor's duties in conducting teacher training.
\end{abstract}

Keywords--component: model coaching, school supervisors, professional teachers

\section{INTRODUCTION}

School supervisors are the task of academic oversight and managerial oversight, with respect to the implementation of professional coaching, monitoring, assessment and guidance tasks and teacher training on teacher competency and teacher duties [1]. School supervisors are required to take an active role in developing professional organizations of school supervisors and official organizations. Organizations can be used as a vehicle to improve the professionalism and care of school supervisors in carrying out their professional duties. School supervisors are educational personnel in the formal education path. The existence of school supervisors is a constitutional mandate that has important duties and positions as one of the components in the national education system. The school supervisor is the only functional position that has the main task of supervising. Thus the school supervisor is the main supervisor in the school education activities [2]. The essence of supervision activities is teacher coaching [3].

In reality, in performing professional duties, the teacher has not shown adequate performance [4]. This is apparent in the case of: (1) the ability of students is not maximally in absorbing subjects taught by teachers; (2) imperfect character formation reflected in the attitude and life skills of each student; and (3) low literacy, writing and numeracy skills at elementary level [5]. Furthermore, adding adds that the low performance of teachers due to the lack of teacher development competencies reflecting the needs. Following up on the problems of teachers in carrying out professional duties, the government made improvements by programming teacher development activities. One example of teacher performance improvement activities is through the assistance of a supervisor, a person who carries out supervision of the teacher [6]. Further stating that the supervision of education is the refinement of teaching as a step of increasing the professional teacher position integrated with the individual needs of educational goals and the main task of the school [7]. More specifically define that academic supervision is to help teachers learn how to improve their abilities and abilities, so that learners can realize the learning objectives that have been set. Educators and education personnel are obliged to have a professional commitment to improve the quality of education [8]. From the article it is known that educators, who are often called teachers are required to carry out their professional obligations in order to improve the quality of education, because teachers are the main actors in the implementation of learning. In line with the demands of the law, another opinion states that education and graduates are the process of teaching and learning in the teaching and learning process that is the responsibility of the school [9].

Teacher profession is a special field of work performed on the following principles: (a) possessing talent, interest, calling of soul, and idealism; (b) have a commitment to improve the quality of education, faith, piety, and noble character; (c) have academic qualifications and educational background in accordance with the task field; (d) having the required competencies in accordance with the task field; (e) have responsibility for the performance of professional duties; (f) earning a fixed income in accordance with work performance; (g) have the opportunity to develop professionally advanced 
skills with lifelong learning; (h) having legal protection in performing professional duties; and (i) have professional organizations that have the authority to regulate matters relating to teacher professional duties [10].

Academic supervision is a supervisory function that deals with the aspects of fostering and developing the professional skills of teachers in improving the quality of learning and guidance in schools [11]. Academic Supervision is a coaching activity by providing technical assistance to teachers in implementing the process of targeted learning to improve teachers' professional skills and improve learning quality [12]. The quality of student learning is determined by the quality of the teacher's learning. Given the importance of quality learning, it is necessary coaching and assistance from the head of school assistance in the form of continuous academic supervision with the aim that the teacher learning process in the classroom becomes more qualified and contribute to the improvement of student learning outcomes. The goals of academic supervision are (1) helping teachers develop their ompetency, (2) developing curriculum, and (3) developing teacher working groups, and guiding classroom action research. Academic supervision is one of the fundamental functions in the overall school program. The result of academic supervision serves as a source of information for the development of teacher professionalism.

Model Grow-Me. Grow-me is short for G - Goal, R reality, O - obstacles or O - options, Way Forward - The preferred way to achieve goals, M-Monitoring - E-Evaluation. In the execution of this model can be done by one person or several, or many people. A teacher can be trained individually. It can also be done in groups. Teacher Competency Improvement Formulating Indicators of Competency Achievement that Meets High Thinking Skills Criteria. Coaching techniques using the GROW-ME model is a coaching model oriented to human development; (1) G (goal)Determine the objectives; (2) R-Reality (current circumstances); (3) O-Obstacle -Option (constraint alternative); (4) W-Way Forward (The preferred way to achieve the goal); (5) M-Monitoring; and (6) E-Evaluation.

SMARTER. The preparation of supervisory programs is the supervisory activities of schools in formulating academic and managerial supervision programs, teacher and / or principal guidance programs, monitoring programs for the implementation of the National Education Standards and teacher performance and / or principal assessment programs as well as teacher and / or principal. In preparing the supervisory program, the school supervisor is obliged to provide an explanation of the following questions. What: What are the goals and objectives of monitoring? Who: Who is involved in surveillance? When: When is supervision done? Where: Where is supervision done? Why: Why is supervision done? How: How is supervision done?

Monitoring program must be "SMARTER" so that the monitoring program contains specific program, measurable achievement, in accordance with the condition of the target school, not making it up, clear the time of implementation, can be objectively assessed, and can be reviewed according to the needs of various conditions at school, or in this work guide is called SMARTER, including: (1) Specific and motivated; (2) Measureable; (3) Achieveable; (4) Realistics; (5) Time bound; (6) Evaluated; and (7) Reviewed. Furthermore, what is done in the preparation of program supervision activities is to prepare and have annual supervision program of the target schools consisting of six aspects, namely: identity, introduction, evaluation of the results of the previous year supervision program, annual school supervision program, school supervision semester program, academic supervision and managerial oversight plan, cover and attachment.

Various problem constraints faced in direct coaching, among others: the unbalanced number of supervisors with the number of teachers built as well as the breadth of the target area [14]. Therefore, it should be an indirect coaching technique that can overcome direct coaching constraints, more encouraged to be done by school superintendents. School supervisors can use a coaching model that can have a positive impact on the development and improvement of the quality of teachers and principals. This study is limited in academic coaching (teacher) in achieving professionalism of teachers in accordance with the objectives set in the school supervision program.

The purpose of this research is; (1) to describe and analyze the factual model of guidance of school supervisors to improve professional teachers of Vocational High School, (2) develop model of school supervisor to improve professionals of vocational teachers and (3) test the application of supervisory school model to improve the professional of vocational teachers.

\section{METHOD}

This research is research and development. This research adopts the steps of research and development. Stages include the preliminary study stage, development stage and model validation stage. Determination of research methods related to the general purpose of research is developing a model of teacher development that can be used by school supervisors to support the implementation of teacher coaching duties. Model trials are conducted to collect data that can be used as a basis for determining the effectiveness, efficiency and or attractiveness of the resulting model. The design of product trials is done by applying the product significantly to a school supervisor. The location and subjects of the study were Vocational High School supervisors in Medan. Research at this stage uses a quantitative descriptive approach

The research was conducted at Vocational High School Negeri in Medan City consisting of 14 vocational schools which was held in the academic year 2016/2017. The subject of research is principal and teacher of Vocational High School in Medan City. Techniques and data collection tools using questionnaires, interviews and documentation studies. The research procedure consists of five stages: (1) Preliminary Studies (Preliminary), the researchers conducted a preliminary study on the potential and problems that exist in Vocational High School Negeri Medan. The preliminary study was conducted by interviewing the principal, completing the questionnaire by the class teacher and studying the 
documentation about the profile, the pedagogical grade teacher's competency assessment format and the supervision implementation form, (2) Data Collection, the researcher collected data in the form of research result from the literature study conducted through literature study (book survey) on supervisory model for school principal, (3) Development of Design, researcher develop mentoring guide design based on preliminary study result and data collection; (4) Design Validation, validation stages or assessment of the experts using delphi techniques with media questionnaires. There are at least two rounds of delphi to produce a model design of good academic supervision of good classroom mentoring techniques; (5) Design Revision, the result of the expert's assessment of the academic supervision model of the mentoring technique is followed up by making improvements to the model.

\section{RESULTS}

Based on the results of the research and development described there are five stages of the language in this study, covering: (1) Preliminary Study (Potential and Problem), (2) Data Collection, (3) Product Design, (4) Design Validation, and (5) Design Repair. The results of the preliminary study as initial data in the development of professional teacher coaching models in vocational schools, including documentation data, interview data, and questionnaire data. Preliminary data obtained through interviews with teachers and principals can be summarized as follows: (1) The potential in supervision planning conducted by the principal lies in the source used as a reference in planning the instrument of the department; (2) References in use are the supervisory instruments of the agency in the form of learning activity planning instruments, classroom observation instruments, advisory instruments for the implementation of learning (peer teaching) and advisory instruments of lesson plan; (3) The form of planning through observation KBM when teachers are carrying out learning activities. Then another form of planning through sharing with teachers in school attendance. Usually teachers convey problems experienced in the learning activities that will become data/input; (4) External factors in my opinion because of the supervision or periodic supervision of the agency that makes teachers should be ready when supervised; (5) Implementation of principal supervision evaluation mentioned about the gradual evaluation done while looking at the progress of the supervised teacher itself; (6) The problems found in the planning section are the first, no specific guidance has been made by the principal; (7) There is no specific teacher competency to be achieved but more focused on the implementation of the 2013 curriculum, which is competence in planning learning activities and implementation of learning activities that will indirectly evaluate to where the teacher competence related to the planning and implementation of learning activities; (8) Guidance obtained from the offices is only an instrument of implementation whereas in the supervision exercise related to the 2013 curriculum in which many items that I and the teachers themselves have not so well understood; (9) Supervision planning, principal work load and teacher delay in making lesson plan due to late book distribution process; (10) Supervision has not been conducted periodically and thoroughly. This is because it is still based on urgent needs in accordance with the problems of teachers that occur and based on information on the supervision of the department; and (11) Internal constraints on understanding how to properly evaluate the curriculum in 2013 , so it is necessary to find out what the format of the assessment is, then share it with some of the principals' friends, but the sharing time is still very limited.

Stages of data collection is done through book survey. Based on book survey results, the teacher coaching component included in teacher professional development model among others, teacher coaching concept and technique. Coaching consists of, the concept of teacher development, the role of teacher development, the stages in conducting the developed coaching. As for the instrument of professional development of teacher assessment and evaluation developed from the instrument of Education and Culture of North Sumatra Province.

Product Design Development Model of Academic and Managerial Supervision of Vocational High School

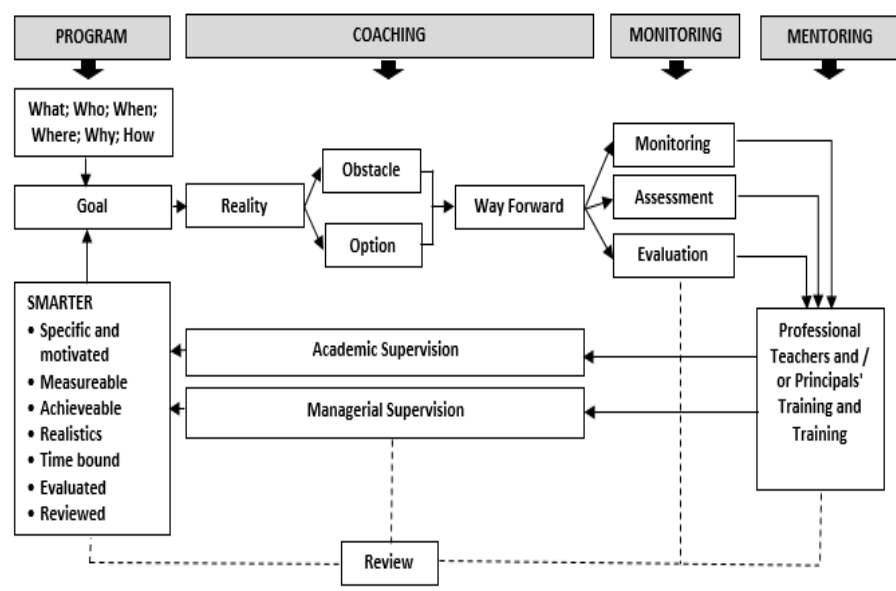

Fig.1. School Supervisory Model of SMARTER-GROW-ME (SGM)

Validation of Model Development Plans 
TABLE I. Teacher response and school head of school activity activities in preparing programs, monitoring, monitoring, assessment and evaluation, leading and professional training teacher and head of school

\begin{tabular}{|c|c|c|c|c|}
\hline \multirow[t]{2}{*}{ No } & \multirow[t]{2}{*}{ Details of School Supervisor's Activities } & \multicolumn{2}{|c|}{ Vocational High School (\%) } & \multirow[t]{2}{*}{ Category } \\
\hline & & Teacher & Headmaster & \\
\hline \multirow[t]{2}{*}{1} & Develop monitoring programs & & & \\
\hline & Develop monitoring programs & 73,67 & & good \\
\hline \multirow[t]{3}{*}{2} & Coaching (Managerial and Academic Supervision) & & & \\
\hline & Implement teacher development (planning, implementation, assessment of learning) & 71,65 & & good \\
\hline & Implementing the principal's guidance in school management and administration & & 72,54 & good \\
\hline \multirow[t]{9}{*}{3} & Monitoring (Managerial and Academic) & & & \\
\hline & Monitor the implementation of content standards & 55,67 & & less \\
\hline & Monitor the implementation of standard process standards & 70,54 & & Enough \\
\hline & Monitor the implementation of graduate competency standards & 61,45 & & Enough \\
\hline & Monitor the implementation of assessment standards & 72,34 & & good \\
\hline & Monitor the implementation of educator standards and education personnel & & 67,56 & Enough \\
\hline & Monitor the implementation of management standards & & 60,33 & Enough \\
\hline & Monitor the implementation of standard facilities and infrastructure & & 72,45 & good \\
\hline & Monitor the implementation of financing standards & & 57,78 & less \\
\hline \multirow[t]{5}{*}{4} & Assessment and Evaluation of teachers and / or principals & & & \\
\hline & Carry out a teacher performance assessment & 67,53 & & \\
\hline & Carry out a principal's performance assessment & & 64,67 & Enough \\
\hline & Conducting evaluation of the results of supervision program implementation in the target schools & & 64,33 & Enough \\
\hline & Evaluate the results of the implementation of provincial / district / municipal supervision programs & & 62,42 & Enough \\
\hline \multirow[t]{14}{*}{5} & Professional Coaching and Training of teachers and / or principals & & & \\
\hline & $\begin{array}{l}\text { Establish mentoring programs and professional training of teachers in KKG / MGMP / MGBK and the } \\
\text { like Prepare mentorship programs and professional training of principals in KKKS / MKKS and the like }\end{array}$ & 63,67 & & Enough \\
\hline & Prepare mentorship programs and professional training of principals in KKKS / MKKS and the like & & 63,23 & Enough \\
\hline & Carry out teacher professional coaching and training & 67,78 & & Enough \\
\hline & Carry out professional coaching and training of principals & & 65,66 & Enough \\
\hline & $\begin{array}{l}\text { Carry out mentoring and training of principals in preparing school programs, work plans, monitoring and } \\
\text { evaluation, school leadership, and information and management systems }\end{array}$ & & 67,32 & Enough \\
\hline & Evaluate the results of teacher guidance and professional training & 67,46 & & Enough \\
\hline & Evaluate the guidance and professional training of the principal & & 64,34 & Enough \\
\hline & Guiding Young School Supervisors in carrying out basic tasks & & 65,23 & Enough \\
\hline & Guiding the Superintendent of the Madya School in carrying out the main task & & 60,56 & Enough \\
\hline & $\begin{array}{l}\text { Carry out professional coaching and training of teachers and principals in the conduct of classroom action } \\
\text { research (PTK) and / or school action research (PTS) }\end{array}$ & & 62,64 & Enough \\
\hline & Carry out supervisory duties in special areas & & 60,53 & Enough \\
\hline & $\begin{array}{l}\text { Development of Profession (composing scientific papers and / or Translation / adaptation of books and / } \\
\text { or scientific work in the field of formal education / supervision and / or creating innovative works) }\end{array}$ & 64,12 & & Enough \\
\hline & Total & 66,89 & 64,47 & Enough \\
\hline
\end{tabular}

Based on data analysis of teacher response and head of school on academic and managerial supervision performed by school supervisors show that overall is enough that is $66,89 \%$ for teacher response and $64,47 \%$ for principal response to school supervisor. The school supervisory activities that have been conducted indicate that the teacher and principal response to each aspect; (1) preparation of supervision program of $73.67 \%$ good category; (2) guidance (managerial and academic supervisor) of $72.09 \%$ good category; (3) Assessment and Evaluation of teachers and / or principals of 64,76\% sufficient category; (4) Professional Coaching and Training of teachers and / or principals of $64.73 \%$ sufficient category.

So in the implementation of school supervision and the response of teachers and principals to all vocational schools in Medan showed less or near enough. This demonstrates the need for comprehensive coaching in these four aspects on an ongoing basis. Therefore the results of data analysis as a reference for the development of a model of coaching is planned.

\section{DISCUSSION}

This research has resulted in the development of SGM supervisory model for Vocational High School based on the essence of managerial supervision as professional assistance to improve the principal's competence, prioritizing the principal's involvement, dialogical communication based on trust, openness, mutual respect on duty, function and authority respectively, equality, also support the improvement of professionalism.

There are a number of studies relevant to the development research that will be conducted. First, a study entitled 'SelfAcademic Teaching Model Based on MGMP Schools to Improve Pedagogical Vocational Teacher Competence in Wonogiri District' shows that the self-evaluation model of academic self-evaluation effectively improves the pedagogical competence of Vocational High School teachers in Wonogiri district [15]. This is seen in the change or improvement of pedagogic competence of teachers after the supervision of the results of development. Second, a study entitled " Competence 
Development Efforts of Pedagogic Teachers in Developing Learning Plans through Mentoring Activities' [16]. The results of this study indicate the success of mentoring activities in an effort to improve teacher pedagogic competence in preparing lesson plans. Third, the study entitled "Teachers and Principals Worries in Instructional Development Master of Academic Mentoring Techniques for the Development of Teacher Class Pedagogic Competencies in Supervision in Three Asian Countries" [17]. This study aims to describe the nature of instructional supervision conducted in schools in three Asian countries namely India, Malaysia and Thailand. The results show that the role of supervisors is only to find teacher error and not improve teacher performance. This study mentions that teachers prefer supervision involving them.

The implementation of academic supervision should be done systematically by supervisors. It aims to provide guidance to teachers in order to perform their duties effectively and efficiently. In addition, as we all know, the teaching-learning process undertaken by the teacher is at the core of the overall educational process with the teacher as the primary role holder.

There are several important meanings why academic supervision activities need to be carried out in the planning as outlined in the academic supervision program, among them: (a) from the programmed supervision activities will be obtained objective data, which in the end can be used to determine the action to be performed in the period (b) wellplanned academic supervision and accompanied by reasonable and healthy considerations, will automatically improve the confidence, recognition and acceptance of all parties involved in this academic supervision activity, (c) supervision activities planned academic activities are those which are conducted with full awareness of the reasons, objectives, and ways of doing so, so that the results can be measurably clear, (d) wellprogrammed academic supervision can serve as an integral part of general education development programs and developers in particular, so the benefits can be felt directly [18].

The competence of educational evaluation is the ability of school supervisors in collecting, processing, interpreting, and summarizing data and information to determine the success rate of education. The main subjects of educational evaluation competency are assessment of process and learning outcome, assessment of education program, teacher performance appraisal, principal performance and school performance. The competence of the evaluation of education consists of six core competencies: (1) Developing criteria and indicators of the success of learning/guidance, (2) Guiding teachers in determining the important aspects assessed in learning/guidance, (3) Assessing the performance of principals, teachers and staff (4) Monitoring the implementation of the learner/guidance and student learning outcomes and their analysis for the quality of learning /guidance, (5) Fostering teachers in utilizing the results of the assessment to improve the quality of education and learning/bombingan, and (6) Processing and analyzing data on performance of school principals, teachers and school staff.
Based on the data collected in the field, it is known that the most commonly used techniques of supervisors are observation techniques or class visits coupled with individual meetings. As for some series of activities undertaken by supervisors are: (1) conducting individual meetings with teachers before making class visits. This meeting is intended to examine the completeness of teacher learning tools that mirror the extent of teacher preparation in teaching, (2) carry out classroom observations in order to assess the performance of teachers teaching in the classroom. With class visits, the supervisor will get more objective data about the actual state as long as the teacher gives class lessons; (3) having an individual meeting with the teacher after completing the class observation. This is intended to reflect on the performance of the teaching teacher as a result of the supervisor's assessment during the observation. At this last individual meeting the supervisor will provide encouragement, assistance with involving classroom teachers in solving problems and constraints faced by teachers. For this reason, the supervisor will open a new view of teachers in order to be more wise in addressing these matters without disrupting the duties and principal functions as a classroom teacher. From the experience that the author has done with the problems faced by the teacher, at the individual meeting the author to solve problems faced by teachers using Grow-me is menaihakan teacher about the goal to be achieved $(G)$, the circumstances faced at that time ( $R$ ), expressed what constraints to achieve the desired objectives and looked for ways to achieve them (O), monitored the activities of the teacher in solving the problems faced by those chosen by the teacher (M), evaluated whether there is already a change using the selected method (E).

Based on the observations that the authors do, it is known that the supervisor has evaluated the performance of teachers. Evaluation activities conducted by supervisors in a planned and systematic. Planned here means that the work has been contained in the academic supervision plan which is divided into annual and semester supervisory plans as described in the previous section. The step is to start coaching by evaluating the teacher's learning program and then proceed with the evaluation of the learning process (teacher performance assessment). Then followed by a personal meeting which contains open discussions between the supervisor and the teacher of the class who was guarded one of them using Coaching model Grow-me.

The coaching dialogue is a major method for inspiring and enhancing the professionalism of teachers [19]. The essence is effective communication between supervisors and supervisors. Finding the job aspect of a supervisor does not involve communication will be a difficulty. How can a supervisor deliver his innovative messages without effective dialogue? Discussions at individual meetings are the exchange of thoughts or opinions through a conversation about a problem to find an alternative solution. Discussion is one of the coaching techniques used by supervisors to develop various skills in the teachers themselves in overcoming various problems or difficulties with how to exchange ideas between one another. Through this technique the supervisor can help teachers to know each other, understand, or explore a problem, 
so that together will try to find an alternative solution to the problem [20].

Academic coaching is a coaching activity by providing technical assistance to teachers in implementing a learning process that aims to improve the professional skills of teachers and improve the quality of learning [21]. The quality of student learning is determined by the quality of the teacher's learning. Given the importance of quality learning, it is necessary coaching and assistance from the head of school assistance in the form of continuous academic coaching with the aim that the process of learning in the classroom teachers become more qualified and contribute to the improvement of student learning outcomes.

The quality of the learning process depends on the ability of the teacher in the learning activities in the classroom, while the quality of learning outcomes is usually indicated by student achievement. If the learning process is not qualified, it can be ascertained $90 \%$ student achievement also will not be good. Conversely, if the process of quality learning then automatically student achievement will be good and satisfactory. The teacher is an adult (who due to his formal position) always strives to create the right situation (teaching) so as to enable the process of learning experience in the student self, by mobilizing all sources and using appropriate teaching and learning strategies [22].

\section{CONCLUSION}

Conclusion as mentioned earlier this research is: (1) Coaching program conducted by the supervisor of teaching in conducting academic coaching is in accordance with the concept of coaching planning and is in accordance with established procedures. This can be seen in the preparation time, insipan things that will be done coaching, planning; (2) The implementation of academic supervision by the supervisor has been effective both seen from the techniques used, as well as the procedure of its implementation. This can be proven by the improvement of teacher discipline and the existence of solutions to teacher constraints related to teacher pedagogic competence. Application of coaching techniques done individually and in groups; (3) The program of supervision and instrument in carrying out the supervision of a supervisor makes the program itself in accordance with the target schools. So that will be in accordance with the necessary and in accordance with the needs of each supervised school Vocational High School supervisors; and (4) School Supervisors in conducting coaching is done consistently especially in providing coaching through academic coaching. Choosing the right techniques in this paper the author in carrying out coaching using SGM school supervisory model. By selecting the SGM school supervisory model model, the principal or teacher is more active and able to solve the problem on its own according to the situation and condition of the person and the school institution itself.
[1] Guidance work of school supervisors of primary and secondary education, ministry of education and culture directorate general of teachers and education personnel directorate of education personnel training primary and secondary education 2017

[2] Sutisna. Perilaku Konsumen dan Komunikasi Pemasaran. Bandung: PT. Remaja Rosdakarya, 1983, p. 230.

[3] K. Masaong, Supervisi Pembelajaran dan Pengembangan Kapasitas Guru: Memberdayakan Pengawas sebagai Gurunya Guru. Bandung: Alfabeta. 2013, p.6.

[4] S., Danim, Inovasi Pendidikan: Dalam Upaya Peningkatan Profesionalisme Tenaga Kependidikan. Bandung: Pustaka Setia, 2010,

[5] Slameto. Implementasi Eksplorasi, Elaborasi, dan Konfirmasi dalam Pembelajaran Guna Meningkatkan Kompetensi Pedagogik Guru SD. Salatiga: Tisara Grafika. 2013

[6] Mukhtar \& Iskandar. Orientasi Baru Supervisi Pendidikan. Jakarta: Gaung Persada Press, 2010.

[7] S. Sagala. Supervisi Pembelajaran dalam Profesi Pendidikan. Bandung: Alfabeta, 2010

[8] Dalam Undang-undang Republik Indonesia Nomor 20 Tahun 2003 Tentang Sistem Pendidikan Nasional, Jakarta: Depdiknas. Bab XI pasal 40 ayat 2 b, 2003.

[9] A.J. Hariwung, 1989. Supervisi Pendidikan. Jakarta: Departemen P dan K, 1989.

[10] Depdiknas, 2005. Undang-Undang Nomor 14 Tahun 2005, Tentang Guru dan Dosen, Jakarta: Depdiknas., tepatnya Bab III Pasal 7.

[11] Mulianto, dkk. Panduan Lengkap Supervisi Diperkaya Perspektif Syariah, Jakarta: Gramedia Mulianto, dkk, 2007, p. 4.

[12] Zuhdi. Teori-Teori Motivasi Jakarta: PT. Raja. Grafindo Persada, 2006.

[13] N. Sujana, Standar Mutu Pengawas, Jakarta, Depdiknas Permendiknas No. 12 Tahun 2007 tentang Standar Pengawas Sekolah/ Madrasah, 2006.

[14] N. Sujana, Standar Mutu Pengawas, Jakarta, Depdiknas Permendiknas No. 12 Tahun 2007 tentang Standar Pengawas Sekolah/ Madrasah, 2011, p. 115.

[15] H. Prihono, Model Supervisi Akademik Bebasis Evaluasi Diri Melalui MGMP Sekolah Untuk Meningkatkan Kompetensi Pedagogik Guru VOCATIONAL HIGH SCHOOL Di Kabupaten Wonogiri. Educational Management Journal UNNES, 2014, 3 (2). 127-132.

[16] E. Mailani, Upaya Pembinaan Kompetensi Pedagogik Guru Dalam Menyusun Rencana Pelaksanaan Pembelajaran Melalui Kegiatan Pendampingan (Mentoring). School Education Journal PGSD FIP UMIMED, 2014, 1(2), pp. 35-41.

[17] S. Sharma, et al. "Concerns of Teachers and Principals on Instructional Supervision in Three Asian Countries." International Journal of Social Science and Humanity, 2011, 1 (3), pp. 214-217

[18] Depdiknas, Penyusunan Program Pengawasan Sekolah (Bahan Pelatihan Pengawas Sekolah). Jakarta: Direktorat Jenderal Peningkatann Pendidik dan Tenaga Kependidikan, 2008.

[19] Komariah Aan, dan Triatna, Admintrasi Dan Supervisi Pendidikan. Bandung: PT. Rosdakarya, 2008.

[20] S. Sagala, Konsep dan Makna Pembelajaran . Bandung: Penerbit Alfabeta. Zuhdi. 2006. Teori-Teori Motivasi Jakarta: PT. Raja. Grafindo Persada, 2005.

[21] Zuhdi. Teori-Teori Motivasi Jakarta: PT. Raja. Grafindo Persada, 2006.

[22] S.A. Makmun, Psikologi Pendidikan. Bandung: Rosda Karya Remaja, 2003. 